\title{
Glaucium species seed germination at different salinity levels as influenced by growth regulators
}

\begin{abstract}
Salinity is considered the major factor that reduces plant growth in arid and semiarid regions where soil salinity is naturally high and precipitation is insufficient to achieve proper leaching. Horned Poppies (Glacium spp) are members of the Poppy family, Papaveraceae and native to the Mediterranean and Middle East regions. The easiest way to grow Horned Poppies is seeding where they are to bloom in the ground in fall and thinning them to the desired spacing the following spring. There are no reported seed germination trials on Glaucium species under saline conditions or how growth regulators may improve Glaucium seed germination percentage and speed. The objectives of this study were (1) to determine if applications of ethephon, fusicoccin, kinetin and thiourea could promote Glaucium spp seed germination under different salinity levels; (2) to determine the most effective concentrations of each growth regulator in enhancing Glaucium spp germination under saline conditions. Without pretreatment, Glaucium spp seeds have a low germination due to seed dormancy. Experiments were conducted to test the effect of the application of different concentrations of thiourea, fusicoccin, ethephon, and kinetin on horned poppy seed germination under three salinity levels. On average, horned poppy germination percentage ranged from $30 \%$ in Glaucium corniculatunm to $74.8 \%$ in G. flavum under nonsaline condition. Germination was reduced to 15 and $50.2 \%$ at 15 and $30 \mathrm{dSm}-1$ salinity levels, respectively. Analysis of variance indicated a significant difference among tested chemicals at $\mathrm{EC}=0.0 \mathrm{dSm}-1$ and $\mathrm{EC}=15 \mathrm{dSm}-1$ and $\mathrm{EC}=30 \mathrm{dSm}-1$ (Table 1) in their effect on enhancing Glaucium spp seed germination percentage and speed of germination. In conclusion, a variation in germination percentage and speed among the tested species has been indicated. Glaucium flavum achieved the highest germination percentage and speed under all salinity levels followed by G. acutidentatum and G. grandiflorum while G. corniculatum had the lowest
\end{abstract}

\section{Abbreviations: EC, electrical conductivity}

\section{Introduction}

Salinity is considered as the major factor that reduces plant growth in arid and semiarid regions where soil salinity is naturally high and precipitation is insufficient to achieve proper leaching. Horned Poppies (Glacium spp) are members of the Poppy family, Papaveraceae, native to the Mediterranean and Middle East regions. Horned poppies grow best in full sun and in well-drained soil. The easiest way to grow Horned Poppies is seeding in the fall where they are to bloom and thinning them to the desired spacing with spring germination. G. flavum Crantz is the most widely spread species in the genus. It's found along the coasts of Britain and the Atlantic Islands to the coasts of the Mediterranean Basin and the Black Sea. ${ }^{1}$ It grows predominantly on sandy beaches and as a result it is commonly known as the Sea Horned Poppy. This implies that G. flavum is relatively salt tolerant due to its proximity to the sea. G. grandiflorum Boiss \& É. Huet is native in the southern part of the Caucasus Mountains in Turkey but is also found in Syria, Iran and the Sinai. ${ }^{1}$ There are two varieties of G. grandiflorum: var. grandiflorum and var. torquatum. G. grandiflorum var. torquatum has red petals with a black blotch and can be found in calcareous hillsides. G. grandiflorum var. grandiflorum is found in fields, banks and rocky slopes. G. acutidentatum Hausskn \& Bornm is endemic to Turkey where it is found on dry hillslopes and rocky places. ${ }^{1}$ It is the most glabrous species with smooth sepals and ovaries. G. corniculatum (L.) J.H. Rudolph is native to the Mediterranean basin, Atlantic islands, Caucasus Mountains, Bulgaria,
Volume 3 Issue 2 - 2019

\section{Ahmed O Getlawi, Mohamed A Shahba, Harrison $G$ Hughes \\ Department of Horticulture \& Landscape Architecture,} Colorado, USA

Correspondence: Mohamed A Shahba, Department of Horticulture \& Landscape Architecture, Fort Collins, Colorado, 80523-II73, USA, Email shahbam@lamar.colostate.edu

Received: March 07, 2019 | Published: April 25, 2019

germination percentage and speed. The effect of growth regulators varied from species to species and from one salinity level to the other. The current investigation demonstrated that $30 \mathrm{mM}$ thiourea, $0.01 \mathrm{mM}$ fusicoccin, 10.0 $\mathrm{mM}$ ethephon, and $1.5 \mathrm{mM}$ kinetin increased seed germination percentage and speed of Glaucium spp under saline conditions. Ethephon was the most effective growth regulator in ameliorating salinity effect on Glaucium spp seed germination followed by thiourea, fusicoccin and kinetin. All tested growth regulators had similar positive effects at the highest salinity level $(E C=30$ $\mathrm{dSm}-1)$. Further research is needed to develop appropriate protocols for practical and effective treatment procedures for landscape use in saline areas.

Keywords: horned poppies, germination percentage, germination speed, ethephon, fusicoccin, kinetin, thiourea

Romania, northern Iraq and northwestern Iran. ${ }^{1,2}$ G. corniculatum also has some unique characteristics which are soft leaves, villous texture and sepals that are scabrous to hirsute. Although there is some conflicting information about G. corniculatum's corolla, its petals have been observed to be yellow, orange or red $^{2}$ with a black basal spot. ${ }^{1}$

Previous research on Glaucium flavum seed germination has clearly indicated a need to stratify the seeds which have seed coat dormancy (hard seed). Previous research has also verified that G. flavum germinates better in cooler temperatures and that light can interact with germination at warmer temperatures (breaking a surfacegermination avoidance mechanism) but light impedes germination at cooler temperatures. A combination of stratification type of scarification has been tested too ${ }^{3-8}$ with some success. Walmsley and Davy ${ }^{7}$ compared the seed germination of G. flavum under different levels of salinity to mimic the sea water normally found on coasts. Germination in G. flavum dropped dramatically at $20 \%$ salinity. They found that unripe seeds germinated readily and verified that G. flavum seeds have a hard seed coat dormancy as reported by Scott. ${ }^{3}$ As seed aged, they showed an increased sensitivity to supra-optimal temperatures. Therefore, they concluded that reduced germination in older seeds is not necessarily due to lower viability but because of growing sensitivity to inappropriate conditions such that the optimal environmental conditions has a more narrow range; this is likely a symptom of decreased vigor.

The effects of germination regulating chemicals in enhancing seed germination under salinity conditions and alleviating salinity stress 
has been reported many plant species. Gul and $\mathrm{Khan}^{9}$ demonstrated a substantial enhancement in seed germination of the perennial halophyte Utah pickleweed (Salicornia utahensis Tidestrom) with the inclusion of ethephon, (an ethylene releasing compound) at $10 \mathrm{mM}$ and kinetin $0.05 \mathrm{mM}$. Ethylene may stimulate seed germination, ${ }^{10,11}$ especially when seeds are exposed to salt and temperature stresses. ${ }^{12}$ El-Keblawy et al. ${ }^{13}$ reported a positive effect of $0.05 \mathrm{mM}$ kinetin in enhancing the germination at high salinity levels in mesquite [Prosopis julifl ora (Sw.) DC.]. While Khan and Ungar ${ }^{14}$ reported that thiourea $(10 \mathrm{mM})$ partially alleviated the inhibitory effects of salinity on the germination of summer seeds of coastal dune grass [Halopyrum mucronatum (L.) Stapf], while kinetin $(0.05 \mathrm{mM})$ alleviated the inhibitory effects of salinity on the germination of winter seeds. Fusicoccin is known to alleviate the effect of salinity on seed germination of halophytes. ${ }^{15-18}$ Shahba et al. ${ }^{19,20}$ have found a positive effect for thiourea, fusicoccin, kinetin and ethephon on saltgrass seed germination under saline conditions. It is still to be determined if other Glacium species will germinate under similar conditions and there have been no trials to improve Glacium species seed germination under saline conditions.

There is no reported seed germination trial on Glaucium species, under saline conditions and with use of growth regulators to improve seed germination percentage and speed. The objectives of this study were (1) to determine if applications of ethephon, fusicoccin, kinetin and thiourea could promote Glaucium spp seed germination under different salinity levels;(2) to determine the most effective concentrations of each growth regulator in enhancing Glaucium spp germination under saline conditions.

\section{Materials and methods}

Seed Acquisition. Glaucium seeds were acquired from Denver Botanic Garden's collection. Glaucium species studied were as follows; G. flavum, G. acutidentatum, G. grandiflorum and G. corniculutatum. All four species are grown in the Rock Alpine Garden with an area of 43,560 ft2 or approximately $4046.9 \mathrm{~m} 2$. Seeds were stored at room temperature prior to initiation of these studies.

Viability Testing. A seed is considered viable if the embryo is alive and will germinate. The viability of the seeds was tested with a $1.0 \%$ concentration of 2,3,5-triphenyltetrazolium chloride (TZ). The testing method used was in accordance with the standards set by the Association of Official Seed Analysts (AOSA) for seeds of the Papaveraceae. Two replications of 100 seeds from each seed lot were set on moist blotter paper to soften overnight. Off-center, longitudinal cuts were made into the seeds and they were then placed in petri dishes containing $1.0 \% \mathrm{TZ}$. The dishes were set in a dark store room at $19^{\circ} \mathrm{C}$ overnight (approximately 8 hours). Viability was determined based on diagrams and descriptions of Papaver sp. seed staining in the AOSA handbook. Viability tests were performed on seeds prior to the combined stratification/scarification treatment.

\section{Germination test}

Without pretreatment, Glaucium spp seeds have low germination due to seed dormancy. To break seed dormancy, seeds were subjected to machine scarification using the MAT-OSU pneumatic seed scarifier, Mater Intel., Corvallis, OR). A series of pilot tests were performed to determine the appropriate sandpaper grit size, appropriate operation pressure of the scarifier and scarification time for optimum results. In this experiment the seed scarifier was set at $112 \mathrm{MPa}$ pressure with 60 Grit sandpaper used, and a scarification time of $4 \mathrm{~min}$. In the stratification treatment, scarified seeds were placed on moist paper towels and stored at $4^{\circ} \mathrm{C}$ in darkness for 3 weeks. Three treatment factors were imposed: salinity, type of germination-regulating chemical, and concentrations of germination-regulating chemical. The experiment was set up in the growth chamber and repeated once. A split-split plot design with three replications was used. Salinity levels were considered as the whole plot factor, germination-regulating chemicals were the subplot factor, and the concentrations of these chemicals were the sub-subplot factor. Salinity levels were control (distilled water), and electrical conductivity (EC) of 5,15 and 30dSm1 (salinity levels were determined based on preliminary studies using various $\mathrm{NaCl}$ concentration to prepare EC solutions. Chemicals used to stimulate seed germination were thiourea, fusicoccin, ethephon and kinetin. Four different concentrations of each were used: thiourea $(0.00,10,20$ and $30 \mathrm{mM})$, fusicoccin $(0.0,3.0,5.0$, and $10.0 \mu \mathrm{M})$, ethephon $(0.0,3.5$ and $10 \mathrm{mM})$ and kinetin $(0.0,0.5,1.0,1.5 \mathrm{mM})$. All solutions were prepared using $\mathrm{NaCl}$ solutions at 0,15 , and $30 \mathrm{dSm}-1$, respectively.

Seeds were sown on sterile germination blotter papers lined in 9-cm diameter petri dishes. In each dish, 50 seeds were placed on each germination blot. Germination blots were moistened with $20 \mathrm{~mL}$ of each treatment solution. Petri dishes were sealed with parafilm and were placed in a germinator at the Colorado State Seed Laboratory, at $15^{\circ} \mathrm{C}$ at $+/-0.6^{\circ} \mathrm{C}$. The germinator's light source was $6 \mathrm{cool}$, white fluorescent bulbs, which emits approximately $10.25 \mu \mathrm{mol} \mathrm{s}-1 \mathrm{~m}-2$ of light. The germinator was set to give 16 hours of light and 8 hours of dark. Germination was recorded every other day after 2 days until 20. Seeds were considered germinated if the emerged radical was visible. Germination percentage was defined as the total percent germination in $20 \mathrm{~d}$. The speed of germination was calculated by dividing the percentage of seeds germinated at each count by the number in days from the start of the germination test. The total of values obtained is the germination speed (Maguire 1962). The experiment was repeated twice.

\section{Data analysis}

The data of the two experiments were subjected to ANOVA to test the experiment effect and the interaction between treatments and experiments. Experiments were not significant different. Therefore, data were pooled over experiments to test the effects of salinity levels and different concentrations of each chemical treatment on germination speed and percentage at individual salinity levels. ${ }^{21}$ Means separation were performed at $\mathrm{P}=0.05$ by Fisher's LSD test when significant differences were found. The most effective concentration of each chemical treatment was chosen and subjected to ANOVA for chemical treatment comparison.

\section{Results and discussion}

Analysis of variance indicated significant species, salinity, chemical type, and concentration effects on the four Glaucium ssp. seed germination percent and speed. The interactions between species and growth regulators, chemical type and concentration, and among species, growth regulators and concentrations were also significant (Table 1). The increase in salinity significantly reduced the germination percentage and speed of the four Glaucium ssp. (Figure 1). G. flavum achieved the highest germination percentage under non saline conditions $(74.8 \%)$, followed by G. acutidentatum (50\%), G. grandiflorum (39.7\%), and G. corniculatum (30\%). All Glaucium species were affected negatively by the increase in the salinity level. Effects of $\mathrm{NaCl}$ on seed germination could be osmotic and/or ionic 
either through reduction of water availability, interference with some aspect of metabolism, or altering the balance of endogenous growth regulators in the seeds. ${ }^{22-24}$ Shahba et al..$^{19,20}$ found the same effect on saltgrass seed germination under saline conditions.

Thiourea significantly improved germination percentage (Figure 2) and germination speed (Figure 3) of the four Glaucium ssp. at all salinity levels. Analysis of variance and a means separation test indicated that $30.0 \mathrm{mM}$ of thiourea was the most effective concentration of those tested in improving both germination speed and percentage at all salinity levels (Table 2). The level of $30.0 \mathrm{mM}$ of thiourea increased germination percentage at $\mathrm{EC}=0.0 \mathrm{dSm}-1$ from 74.8 to $92.2 \%$, at $\mathrm{EC}=15 \mathrm{dSm}-1$ from 68.7 to $73.8 \%$, and at $\mathrm{EC}=30$ dSm-1 from 50.2 to $64.7 \%$ in G. flavum. Thiourea concentration of $30.0 \mathrm{mM}$ had a similar effect on germination speed (Table 3 ). In this species, the level of $30.0 \mathrm{mM}$ of thiourea increased germination speed at $\mathrm{EC}=0.0 \mathrm{dS} \mathrm{m}-1$ from 20.8 to $29.0 \%$, at $\mathrm{EC}=15 \mathrm{dSm}-1$ from 17.2 to 19.3, and at $\mathrm{EC}=30 \mathrm{dSm}-1$ from 13.0 to 17.2. In G. acutidentatum, the concentration at $30.0 \mathrm{mM}$ improved seed germination percentage and speed the greatest of those tested. At an $\mathrm{EC}=0.0 \mathrm{dSm}-1$, germination percentage increased from 50.0 to $82.0 \%$, while seeds at $\mathrm{EC}=15 \mathrm{dSm}-$ 1 increased from 45.2 to $60.5 \%$ and at $\mathrm{EC}=30 \mathrm{dSm}-1$ increased from 35.0 to $50.7 \%$. Thiourea had a similar effect on germination speed. The level of $30 \mathrm{mM}$ achieved the greatest germination speed followed by $20 \mathrm{mM}$ and $10 \mathrm{mM}$ (Table 3 ). The level of $30.0 \mathrm{mM}$ of thiourea increased germination speed of $\mathrm{G}$. acutidentatum at $\mathrm{EC}=0.0 \mathrm{dSm}-1$ from 9.3 to 19.0 , at $E C=15 \mathrm{dSm}-1$ from 7.8 to 13.0 and at $\mathrm{EC}=30$ $\mathrm{dSm}-1$ from 5.5 to 8.5 . The level of $30 \mathrm{mM}$ increased germination percentage at $\mathrm{EC}=0.0 \mathrm{dSm}-1$ from 39.7 to $72.2 \%$, at $\mathrm{EC}=15 \mathrm{dS} \mathrm{m}-1$ from 29.5 to $52.7 \%$, and at $\mathrm{EC}=30 \mathrm{dSm}-1$ from 19.7 to $32.5 \%$ in $\mathrm{G}$. grandiflorum. In the same species, the level of $30.0 \mathrm{mM}$ of thiourea increased germination speed at $\mathrm{EC}=0.0 \mathrm{dSm}-1$ from 10.9 to 17.4 at $\mathrm{EC}=15 \mathrm{dSm}-1$ from 8.5 to 13.6 and at $\mathrm{EC}=30 \mathrm{dSm}-1$ from 7.0 to 9.5 . G. corniculatum had the lowest germination percentage and speed even under the optimum thiourea concentration. The level of $30.0 \mathrm{mM}$ of thiourea increased germination percentage at $\mathrm{EC}=0.0 \mathrm{dSm}-1$ from 30.7 to $58.0 \%$, at $\mathrm{EC}=15 \mathrm{dSm}-1$ from 20.7 to $38.0 \%$, and at $\mathrm{EC}=30$ $\mathrm{dSm}-1$ from 15.2 to 30.0 . Thiourea concentration of $30.0 \mathrm{mM}$ had a similar trend of effect on germination speed (Table 3 ). The level of 30.0 $\mathrm{mM}$ of thiourea increased germination speed at $\mathrm{EC}=0.0 \mathrm{dSm}-1$ from 5.5 to $14.5 \%$, at $\mathrm{EC}=15 \mathrm{dSm}-1$ from 3.3 to 7.5 , and at $\mathrm{EC}=30 \mathrm{dSm}-1$ from 2.2 to 5.0. The role of thiourea in alleviating salinity effects on seed germination has been well established in many halophytes. ${ }^{24-26,19}$ These results are consistent with previous investigations that demonstrated the effectiveness of thiourea in ameliorating salinityinduced inhibition of germination. Thiourea has alleviated the salinity induced dormancy in summer seeds of Halopyrum mucronatum, ${ }^{27}$ Sporobolus arabicus, ${ }^{23}$ Salicornia rubra, ${ }^{17}$ Atriplex prostrata, ${ }^{28}$ Zygophyllum simplex, ${ }^{29}$ Aeluropus lagopoides, ${ }^{30}$ Triticum aestivum L. ${ }^{31}$ and Disticlis spicata Grene. ${ }^{19}$ Thiourea has been used partially alleviated the germination inhibition under saline conditions in mesquite, ${ }^{13}$ seaside arrow grass, ${ }^{27}$ and iodine bush. ${ }^{16}$ The fact that thiourea stimulates seed germination and reduces the negative effects of salinity on germination indicates its importance as a compatible osmoregulator. ${ }^{16}$ Eashi et al. ${ }^{32}$ found that nitrogenous compounds such as thiourea could promote germination by acidification and softening of cell walls, or by activating the pentose phosphate pathway. Salinity causes a reduction in growth promotors (cytokinins and gibberellins) and increases in ABA in seeds. ${ }^{33}$

Thiourea may counteract this effect, controlling the adverse changes through a balance of hormonal promotors and inhibitors.
Germination percentage (Figure 2) and speed (Figure 3) of Glaucium ssp. were significantly improved by the presence of fusicoccin in the germination solution on the blotter paper at all salinity levels. Analysis of variance and means separation test indicated that the level of $0.01 \mathrm{mM}$ of fusicoccin was the optimum level of those tested in ameliorating the effect of salinity on Glaucium ssp. seed germination at all salinity levels. It increased germination percentage from 74.8 to 91.3, from 68.7 to 72.7 and from 50.2 to 51.3 in the control treatment, at $\mathrm{EC}=15 \mathrm{dSm}-1$ and at $\mathrm{EC}=30 \mathrm{dSm}-1$ respectively in G. flavum (Table 2). Fusicoccin concentration of $0.01 \mathrm{mM}$ similarly affected the germination speed (Table 1) (Table 2) (Table 3). At a level of $0.01 \mathrm{mM}$ fusicoccin increased germination speed at $\mathrm{EC}=0.0 \mathrm{dSm}-1$ from 20.8 to $27.7 \%$, at $\mathrm{EC}=15 \mathrm{dSm}-1$ from 17.2 to 19.1 , and at $\mathrm{EC}=30 \mathrm{dSm}-1$ from 13.0 to 14.5 . In G. acutidentatum, the level of $0.01 \mathrm{mM}$ was also optimum in improving seed percentage and speed (Tables 2) (Table 3). At the control treatment, germination percentage increased from 50.0 to $80.3 \%$, while at $\mathrm{EC}=15 \mathrm{dSm}-1$ it increased from 45.2 to $62.8 \%$, and at $\mathrm{EC}=30 \mathrm{dSm}-1$ from 35.0 to $45.0 \%$ (Figure 2). Fusicoccin demonstrated a similar effect on germination speed. The level of $0.01 \mathrm{mM}$ achieved the greatest germination speed followed by $0.005 \mathrm{mM}$ and $0.003 \mathrm{mM}$. The level of $0.01 \mathrm{mM}$ of fusicosccin increased germination speed of $\mathrm{G}$. acutidentatum at $\mathrm{EC}=0.0 \mathrm{dSm}-1$ from 9.3 to 17.7 , at $\mathrm{EC}=15 \mathrm{dS} \mathrm{m}-1$ from 7.8 to 11.8 , and at $\mathrm{EC}=30$ $\mathrm{dSm}-1$ from 5.5 to 7.7 (Figure 3). In G. grandiflorum, the level of 0.01 $\mathrm{mM}$ of fusicoccin again achieved the greatest increase in germination percentage (Table 2) and speed (Table 3) followed by the level of $0.005 \mathrm{mM}$ and the level of $0.003 \mathrm{mM}$. The level of $0.01 \mathrm{mM}$ increased germination percentage at $\mathrm{EC}=0.0 \mathrm{dSm}-1$ from 39.7 to $71.7 \%$, at $\mathrm{EC}=15 \mathrm{dSm}-1$ from 29.5 to $50.7 \%$, and at $\mathrm{EC}=30 \mathrm{dSm}-1$ from 19.7 to $31.2 \%$ (Figure 2). Once again, the level of $0.01 \mathrm{mM}$ of fusicoccin on increasing germination speed at $\mathrm{EC}=0.0 \mathrm{dSm}-1$ from 10.9 to 17.4 , at $\mathrm{EC}=15 \mathrm{dSm}-1$ from 8.5 to 13.1 , and at $\mathrm{EC}=30 \mathrm{dSm}-1$ from 7.0 to 9.2 (Figure 3). G. corniculatum had the lowest germination percentage and speed under all fusicoccin treatments (Table 2). The level of $0.01 \mathrm{mM}$ of fusicoccin increased germination percentage at $\mathrm{EC}=0.0$ $\mathrm{dSm}-1$ from 30.7 to $56.0 \%$, at $\mathrm{EC}=15 \mathrm{dSm}-1$ from 20.7 to $36.0 \%$ and at $\mathrm{EC}=30 \mathrm{dSm}-1$ from 15.2 to 21.0 in G. corniculatum (Figure 2). Fusicoccin concentration of $0.01 \mathrm{mM}$ similarly effected germination speed (Table 3). An increased germination speed at $\mathrm{EC}=0.0 \mathrm{dSm}-1$ from 5.5 to $12.8 \%$, at $\mathrm{EC}=15 \mathrm{dSm}-1$ from 3.3 to 6.8 , and at $\mathrm{EC}=30$ $\mathrm{dSm}-1$ from 2.2 to 5.0 (Figure 3).

Fusicoccin contains three fused carbon rings and another ring which contains an oxygen atom and five carbons. Alleviation of salinity effect on seed germination by fusicoccin has been reported in many halophytes such as Zygophyllum qatarensis Hadidi, ${ }^{15}$ Utah pickleweed, ${ }^{9}$ triangle orache (Atriplex prostrata Boucher ex DC. $)^{28}$ and Disticlis spicata Grene. ${ }^{19}$ Conversely, El-Keblawy et al. ${ }^{13}$ reported the failure of fusicoccin to stimulate germination in mesquite. Fusicoccin may stimulate ATPase during the early phases of germination to facilitate proton extrusion and $\mathrm{K}+$ uptake. ${ }^{34}$ Cocucci et al. ${ }^{35}$ studied the response of radish (Raphanus sativus L.) seeds to osmotic medium and fusicoccin during the early germination stages and indicated that fusicoccin counteracted the inhibitory effect of salinity in the medium by enhancing $\mathrm{H}+$ extrusion and synthesis of malic acid. Lutsenko et al. ${ }^{36}$ suggested that fusicoccin affects the ionic balance, especially the $\mathrm{K}+/ \mathrm{Na}+$ ratio, aiding in ionic homeostasis in seed and embryo. Salinity stress enhances ABA production, which has an inhibitory effect on seed germination. Fusicoccin has been reported to remove the inhibitory effect of $\mathrm{ABA}$ on seed germination by accelerating development and by replacing the requirements for light and endogenous hormones in breaking dormancy. ${ }^{37}$ 

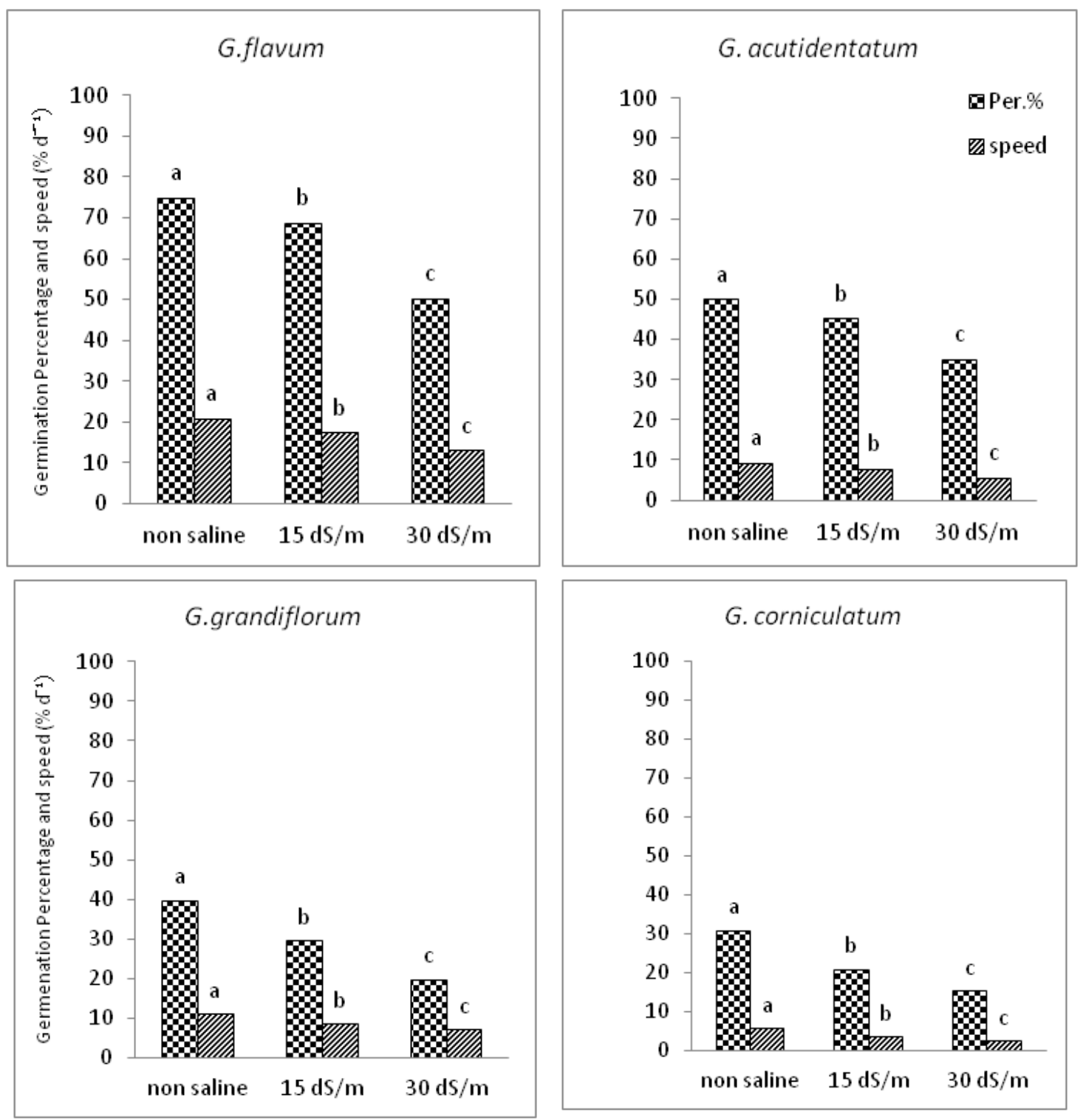

Figure I Effect of different salinity levels on Glaucium. spp. seed germination percentage and speed. Columns labeled with different letters in either percentage or the speed are significantly different at $\mathrm{P}=0.05$ with each salinity level.

Table I Analysis of variance with mean squares and treatment significance of Glaucim Spp. seed germination speed (\% d/I) and percentage (\%) as affected by different growth regulators concentrations and their interaction

\begin{tabular}{|c|c|c|c|c|c|c|}
\hline \multirow{3}{*}{ Source } & \multicolumn{6}{|c|}{ Salinity levels (dS/m) } \\
\hline & \multicolumn{2}{|l|}{0} & \multicolumn{2}{|l|}{15} & \multicolumn{2}{|l|}{30} \\
\hline & speed & $\%$ & speed & $\%$ & speed & $\%$ \\
\hline Species (S) & $425.0 * *$ & $2350.0 * *$ & $110.0^{*}$ & $1512.0^{*}$ & $70.0 * *$ & $249.0 * *$ \\
\hline Growth regulators $(\mathrm{T})$ & $620.0 * *$ & $3340.0 * *$ & $120.0 *$ & $1210.0 *$ & $80.0 * *$ & $369.0 * *$ \\
\hline Concentrations (C) & $800.6 * *$ & $4215.0 * *$ & $620.0 * *$ & $3456.0 * *$ & $540.0 * *$ & $1590.0 * *$ \\
\hline SxT & $659.0 * *$ & $1912.0 * *$ & $299.0 * *$ & $926.0 * *$ & $199.0 * *$ & $396.0 * *$ \\
\hline $\mathrm{TxC}$ & $755.2 * *$ & $2212.0 * *$ & $315.0 * *$ & $1126.0 * *$ & $250.0 * *$ & $462.0 * *$ \\
\hline SxTxC & $856.2 * *$ & $3115.0 * *$ & $429.0 * *$ & $2026.0 * *$ & $340.0 * *$ & $567.0 * *$ \\
\hline
\end{tabular}

*Significant at $\mathrm{P}<0.05$

**Significant at $\mathrm{P}<0.001$

†Not significant at $P<.0 .05$

Citation: Getlawi AO, Shahba MA, Hughes HG. Glaucium species seed germination at different salinity levels as influenced by growth regulators. Horticult Int $J$. 2019;3(2):77-85. DOI: 10.15406/hij.2019.03.00II5 



Figure 2 Effect of different plant growth regulators (Thiourea $30 \mathrm{mM}$, Fusicoccin $0.0 \mathrm{I}$ mM, Ethephon I0 mM, Kinetin I.5 mM) on Glaucium. spp. seed germination percentage under different levels of salinity. Columns labeled with different letters are significantly different at $\mathrm{P}=0.05$ within each salinity level.

Ethephon (2-chloroethyl phosphonic acid), significantly improved germination percentage (Figure 2) and germination speed (Figure 3 ) at all salinity levels. Ethephon at $10.0 \mathrm{mM}$ was the optimum concentration of those tested in relieving the inhibitory effects of salinity on Glaucium ssp. germination percentage (Table 2) and speed (Table 3). The level of $10.0 \mathrm{mM}$ of ethephon increased germination percentage at $\mathrm{EC}=0.0 \mathrm{dSm}-1$ from 74.8 to $97.3 \%$, at $\mathrm{EC}=15 \mathrm{dSm}-1$ from 68.7 to $77.5 \%$, and at $\mathrm{EC}=30 \mathrm{dSm}-1$ from 50.2 to $62.3 \%$ in $\mathrm{G}$. flavum (Figure 2). Ethephon concentration of $10.0 \mathrm{mM}$ had a similar effect on germination speed (Figure 3). In G. flavum, the level of 10.0 $\mathrm{mM}$ of ethephon increased germination speed at $\mathrm{EC}=0.0 \mathrm{dSm}-1$ from 20.8 to $31.0 \%$, at $\mathrm{EC}=15 \mathrm{dSm}-1$ from 17.2 to 20.3 , and at $\mathrm{EC}=30$ dSm-1 from 13.0 to 17.7. In G. acutidentatum, the level of $10.0 \mathrm{mM}$ was also the best in improving seed percentage and speed. At EC $=0.0$ $\mathrm{dSm}-1$, germination percentage increased from 50.0 to $87.7 \%$, at $\mathrm{EC}=15 \mathrm{dSm}-1$ from 45.2 to $66.8 \%$, and at $\mathrm{EC}=30 \mathrm{dSm}-1$ from 35.0 to $53.7 \%$. The level of $10 \mathrm{mM}$ achieved the highest germination speed followed by $5.0 \mathrm{mM}$ and $3.0 \mathrm{mM}$ (Table 3). The level of $10.0 \mathrm{mM}$ of ethephon also increased germination speed of $\mathrm{G}$. acutidentatum at $\mathrm{EC}=0.0 \mathrm{dSm}-1$ from 9.3 to 23.0 , at $\mathrm{EC}=15 \mathrm{dSm}-1$ from 7.8 to 14.6 and at $\mathrm{EC}=30 \mathrm{dSm}-1$ from 5.5 to 12.0. In G. grandiflorum, the level of $10.0 \mathrm{mM}$ of ethephon once again achieved the greatest increase in germination percentage (Table 2) and speed (Table 3) followed by the level of $5.0 \mathrm{mM}$ and the level of $3.0 \mathrm{mM}$. The level of $10 \mathrm{mM}$ increased germination percentage at $\mathrm{EC}=0.0 \mathrm{dSm}-1$ from 39.7 to $71.7 \%$, at $\mathrm{EC}=15 \mathrm{dSm}-1$ from 29.5 to $50.7 \%$, and at $\mathrm{EC}=30 \mathrm{dSm}-$ 
1 from 19.7 to 31.2. In G. grandiflorum, the level of $10.0 \mathrm{mM}$ of ethephon increased germination speed at $\mathrm{EC}=0.0 \mathrm{dSm}-1$ from 10.9 to 17.4 , at $\mathrm{EC}=15 \mathrm{dSm}-1$ from 8.5 to 13.1 and at $\mathrm{EC}=30 \mathrm{dSm}-1$ from 7.0 to 9.2 . G. corniculatum had the lowest germination percentage and speed even under the optimum ethephon concentration. The level of $10.0 \mathrm{mM}$ of ethephon increased germination percentage at $\mathrm{EC}=0.0$ $\mathrm{dSm}-1$ from 30.7 to $70 \%$, at $\mathrm{EC}=15 \mathrm{dSm}-1$ from 20.7 to $48.0 \%$, and
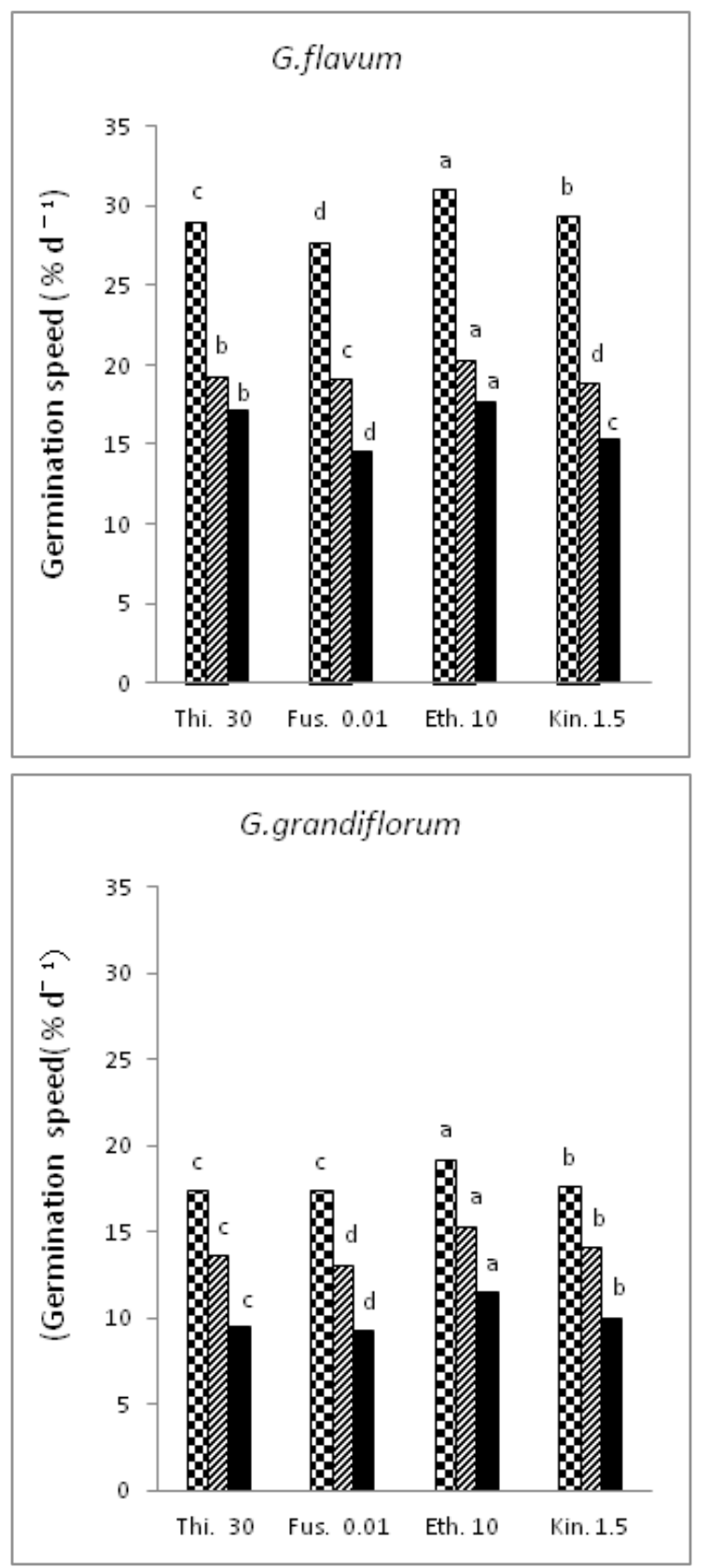

at $\mathrm{EC}=30 \mathrm{dSm}-1$ from 15.2 to 30.0 (Figure 1) (Figure 2). Ethephon concentration of $10.0 \mathrm{mM}$ had a similar trend of effect on germination speed (Figure 1) (Figure 2) (Figure 3). In G. corniculatum, the level of $10.0 \mathrm{mM}$ of ethephon increased germination speed at $\mathrm{EC}=0.0 \mathrm{dSm}-1$ from 5.5 to 18.2 , at $\mathrm{EC}=15 \mathrm{dSm}-1$ from 3.3 to 8.8 , and at $\mathrm{EC}=30$ dSm-1 from 2.2 to 5.0 .
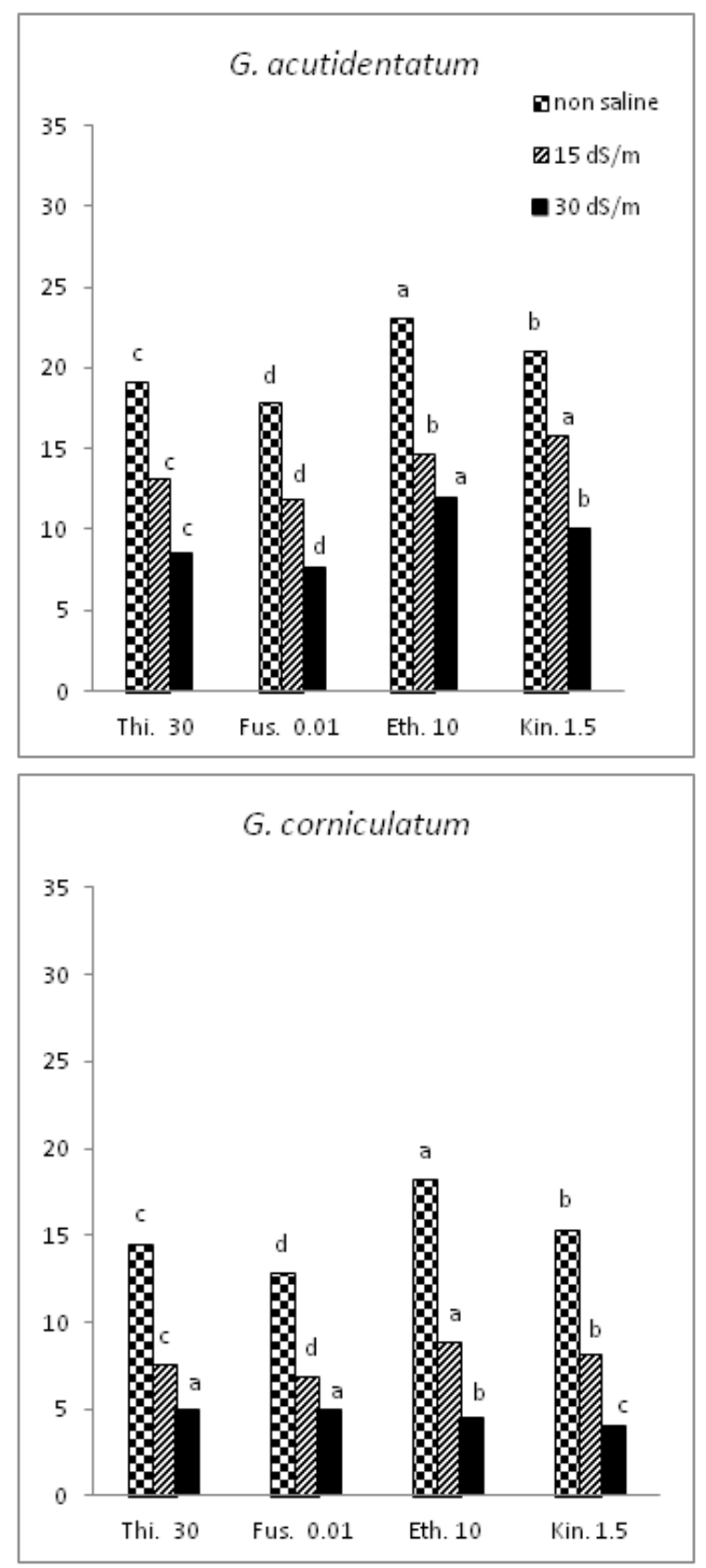

Figure 3 Effect of different plant growth regulators (Thiourea $30 \mathrm{mM}$, Fusicoccin $0.01 \mathrm{mM}$, Ethephon $10 \mathrm{mM}$, Kinetin $1.5 \mathrm{mM}$ ), on germination speed of Glaucium. spp. under different levels of salinity. Columns labeled with different letters are significantly different at $\mathrm{P}=0.05$ within each salinity level.

Ethephon reduced seeds dormancy of several species and reverse the inhibitory effect of abscisic acid (ABA)..$^{38,17-19}$ Ethephon significantly ameliorated the effect of salinity, ranging from 36 to 54 $\mathrm{dSm}-1$ in iodine bush [Allenrolfea occidentalis (S. Wats.) Kuntze], ${ }^{39}$ Utah pickleweed, ${ }^{9}$ and dropseed (Sporobolus ioclados Nees ex Trin). ${ }^{17}$ However, the effectiveness of ethephon in ameliorating salinity- induced dormancy is variable among plant species. It partially alleviated salinity induced dormancy in Arthrocnemum indicum (Wild.) Moq. ${ }^{40}$ and saltwort (Salicornia rubra A. Nels.). ${ }^{17}$ In contrast, it had no effect on seed germination of seaside arrow grass (Triglochin maritima L.) under various salinity levels. ${ }^{27}$ 
Kinetin treatments enhanced Glaucium spp seeds germination percentage (Table 2) and speed (Table 3) under all salinity levels. Analysis of variance and mean separation tests indicated that the level of $1.5 \mathrm{mM}$ of kinetin was the optimum of those tested in improving seed germination percentage (Figure 2) and speed (Figure 3) under all salinity levels. Kinetin at $1.5 \mathrm{mM}$ treatment of G. flavum increased germination percentage from 74.8 to 94.0 , from 68.7 to 72.2 and from 50.2 to 55.7 in the control, at $\mathrm{EC}$ of $15 \mathrm{dSm}-1$, and at $\mathrm{EC}=30 \mathrm{dSm}-1$ respectively in G. flavum (Figure 2). The Kinetin concentration of $1.5 \mathrm{mM}$ had a similar effect on germination speed (Figure 3), in G. flavum. It increased germination speed at $\mathrm{EC}=0.0 \mathrm{dSm}-1$ from 20.8 to $29.3 \%$, at $\mathrm{EC}=15 \mathrm{dSm}-1$ from 17.2 to 18.8 , and at $\mathrm{EC}=30 \mathrm{dSm}-1$ from 13.0 to 15.3. In G. acutidentatum, the level of $1.5 \mathrm{mM}$ was again the optimum in improving seed germination percentage and speed (Tables 2) (Table 3).The control treatment germination percentage increased from 50.0 to $84.0 \%$, at $\mathrm{EC}=15 \mathrm{dSm}-1$ from 45.2 to $64.0 \%$, and at $\mathrm{EC}=30 \mathrm{dSm}-1$ from 35.0 to $48.0 \%$ (Figure 2). Kinetin had a similar effect on germination speed in this species with $1.5 \mathrm{mM}$ with the greatest effect followed by $1.0 \mathrm{mM}$ and $0.5 \mathrm{mM}$. The level of 1.5
$\mathrm{mM}$ of kinetin increased germination speed of $\mathrm{G}$. acutidentatum at $\mathrm{EC}=0.0 \mathrm{dSm}-1$ from 9.3 to 21.0 , at $\mathrm{EC}=15 \mathrm{dSm}-1$ from 7.8 to 15.7 , and at EC $30 \mathrm{dSm}-1$ from 5.5 to 10.0 (Figure 3). In G. grandiflorum, the level of $1.5 \mathrm{mM}$ of kinetin again achieved the greatest increase in germination percentage (Table 2) and speed (Table 3) followed by the level of $1.0 \mathrm{mM}$ and the level of $0.5 \mathrm{mM}$. The level of $1.5 \mathrm{mM}$ increased germination percentage at $\mathrm{EC}=0.0 \mathrm{dSm}-1$ from 39.7 to $73.7 \%$, at $\mathrm{EC}=15 \mathrm{dSm}-1$ from 29.5 to $55.8 \%$, and at $\mathrm{EC}=30 \mathrm{dSm}-1$ from 19.7 to $35.0 \%$ (Figure 2). It's also increased germination speed in $\mathrm{G}$. grandiflorum at $\mathrm{EC}=0.0 \mathrm{dSm}-1$ from 10.9 to 17.6 , at $\mathrm{EC}=15$ $\mathrm{dSm}-1$ from 8.5 to 14.1 , and at $\mathrm{EC}=30 \mathrm{dSm}-1$ from 7.0 to 10.0 (Figure $3)$. G. corniculatum had the lowest germination percentage and speed under all kinetin treatments (Table 2). The level of $1.5 \mathrm{mM}$ of kinetin did however increase germination percentage at $\mathrm{EC}=0.0 \mathrm{dSm}-1$ from 30.7 to $60.7 \%$, at $\mathrm{EC}=15 \mathrm{dSm}-1$ from 20.7 to $45.80 \%$, and at $\mathrm{EC}=30$ $\mathrm{dSm}-1$ from 15.2 to 22.5 (Figure 2). The Kinetin concentration of $1.5 \mathrm{mM}$ had a similar effect on germination speed (Table 3 ). Where it increased speed $\mathrm{EC}=0.0 \mathrm{dSm}-1$ it from 5.5 to $15.3 \%$, at $\mathrm{EC}=15 \mathrm{dSm}-$ 1 from 3.3 to 8.1, and at $\mathrm{EC}=30 \mathrm{dSm}-1$ from 2.2 to 4.0 (Figure 3).

Table 2 Effect of different concentrations of ethephon, fusicoccin, thiourea and kinetin on Glaucium spp seed germination percentage under different salinity levels

\begin{tabular}{|c|c|c|c|c|c|c|c|c|c|c|c|c|c|}
\hline \multirow{3}{*}{ G. Regulator } & \multirow{3}{*}{ Level } & \multirow{2}{*}{\multicolumn{3}{|c|}{$\begin{array}{l}\text { G. acutidentatum } \\
\text { Salinity Level (dS/m) }\end{array}$}} & \multirow{2}{*}{\multicolumn{3}{|c|}{$\begin{array}{l}\text { G. corniculatum } \\
\text { Salinity Level (dS/m) }\end{array}$}} & \multirow{2}{*}{\multicolumn{3}{|c|}{$\begin{array}{l}\text { G. flavum } \\
\text { Salinity Level (dS/m) }\end{array}$}} & \multirow{2}{*}{\multicolumn{3}{|c|}{$\begin{array}{l}\text { G. grandiflorum } \\
\text { Salinity Level (dS/m) }\end{array}$}} \\
\hline & & & & & & & & & & & & & \\
\hline & & 0 & 15 & 30 & 0 & 15 & 30 & 0 & 15 & 30 & 0 & 15 & 30 \\
\hline \multirow[t]{4}{*}{ Thiourea } & $10 \mathrm{mM}$ & $* 60.7 \mathrm{c}$ & $56.7 b$ & $45 b$ & $36.7 c$ & $20.7 c$ & $16.5 c$ & $78.8 c$ & $69.8 b$ & $53.2 c$ & $44.5 c$ & $35.3 c$ & $26.5 c$ \\
\hline & $20 \mathrm{mM}$ & $61.2 \mathrm{~b}$ & $56.7 \mathrm{~b}$ & $45 b$ & $54.5 b$ & $38.5 b$ & $21.2 b$ & $84.3 b$ & $69.8 \mathrm{ab}$ & $59.2 b$ & $60.5 b$ & $42.3 b$ & $29.5 b$ \\
\hline & $30 \mathrm{mM}$ & $82 a$ & $60.5 a$ & $50.7 \mathrm{a}$ & $58.0 \mathrm{a}$ & $38.0 \mathrm{a}$ & $30.0 \mathrm{a}$ & $92.2 \mathrm{a}$ & $73.8 \mathrm{a}$ & $64.7 \mathrm{a}$ & $72.2 \mathrm{a}$ & $52.7 \mathrm{a}$ & $32.5 a$ \\
\hline & Control & $50 d$ & $45.2 c$ & $35 c$ & $30.7 d$ & $20.7 c$ & $15.2 \mathrm{~d}$ & $74.8 d$ & $68.7 c$ & $50.2 d$ & $39.7 d$ & $29.5 d$ & $19.7 d$ \\
\hline \multirow[t]{4}{*}{ Fusicoccin } & $0.003 \mathrm{mM}$ & $55.0 \mathrm{c}$ & $40 d$ & $20.8 d$ & $26.8 d$ & $22.5 b$ & $15.5 \mathrm{~b}$ & $79.2 c$ & $68.7 c$ & $50.2 c$ & $40.7 b$ & $20.8 d$ & $17 d$ \\
\hline & $0.005 \mathrm{mM}$ & $57.7 b$ & $47.7 b$ & $25.8 c$ & $30.3 c$ & $20.5 d$ & $15 d$ & $84.3 b$ & $69.8 b$ & $50.7 b$ & $40.7 b$ & $30.0 \mathrm{~b}$ & $21.2 b$ \\
\hline & $0.01 \mathrm{mM}$ & $80.3 a$ & $62.8 \mathrm{a}$ & $45.0 \mathrm{a}$ & $56.0 \mathrm{a}$ & $36.0 \mathrm{a}$ & $21.0 \mathrm{a}$ & $91.3 \mathrm{a}$ & $72.7 \mathrm{a}$ & $51.3 a$ & $71.7 \mathrm{a}$ & $50.7 \mathrm{a}$ & $31.2 \mathrm{a}$ \\
\hline & Control & $50 d$ & $45.2 c$ & $35 b$ & $30.7 b$ & $20.7 c$ & $15.2 \mathrm{c}$ & $74.8 \mathrm{~d}$ & $68.7 c$ & $50.2 c$ & $39.7 c$ & $29.5 c$ & $19.7 c$ \\
\hline \multirow[t]{4}{*}{ Ethophon } & $3 \mathrm{mM}$ & $64.0 \mathrm{c}$ & $50.5 c$ & $40.2 b$ & $46.8 c$ & $39.2 b$ & $20 b$ & $80 c$ & $69.2 c$ & $51.7 c$ & $51.8 \mathrm{c}$ & $29.7 c$ & $20.7 c$ \\
\hline & $5 \mathrm{mM}$ & $65.7 \mathrm{~b}$ & $5 \mathrm{Ib}$ & $35.3 c$ & $50.7 b$ & $36.7 c$ & $17 c$ & $83 b$ & $74.5 b$ & $55.7 \mathrm{~b}$ & $60.7 b$ & $40.7 b$ & $35.0 \mathrm{~b}$ \\
\hline & $10 \mathrm{mM}$ & $87.7 \mathrm{a}$ & $66.8 \mathrm{a}$ & $53.7 \mathrm{a}$ & $70.0 \mathrm{a}$ & $48.0 \mathrm{a}$ & $25.0 \mathrm{a}$ & $97.3 \mathrm{a}$ & $77.5 \mathrm{a}$ & $62.3 a$ & $76.3 a$ & $61.7 \mathrm{a}$ & $42.5 a$ \\
\hline & Control & $50 d$ & $45.2 d$ & $35 d$ & $30.7 d$ & $20.7 d$ & $15.2 \mathrm{~d}$ & $74.8 d$ & $68.7 d$ & $50.2 d$ & $39.7 d$ & $29.5 d$ & 19.7d \\
\hline \multirow[t]{4}{*}{ Kinetin } & $0.5 \mathrm{mM}$ & $55.2 c$ & $36.2 d$ & $31.7 d$ & $40.3 c$ & $24.7 c$ & $15 d$ & $76.3 c$ & $65.7 d$ & $49.2 d$ & $59.7 c$ & $43.8 c$ & $25.8 \mathrm{bc}$ \\
\hline & $1.0 \mathrm{mM}$ & $61.0 \mathrm{~b}$ & $46.2 b$ & $35.5 b$ & $41.3 b$ & $32 b$ & $17 \mathrm{~b}$ & $78.8 b$ & $69 b$ & $50.5 b$ & $61.7 b$ & $45.8 b$ & $27.8 b$ \\
\hline & $1.5 \mathrm{mM}$ & $84.0 \mathrm{a}$ & $64 a$ & $48.0 \mathrm{a}$ & $60.7 \mathrm{a}$ & $45.8 \mathrm{a}$ & $22.5 a$ & $94.0 \mathrm{a}$ & $72.2 \mathrm{a}$ & $55.7 \mathrm{a}$ & $73.7 \mathrm{a}$ & $55.8 \mathrm{a}$ & $35.0 \mathrm{a}$ \\
\hline & Control & $50 d$ & $45.2 c$ & $35 c$ & $30.7 d$ & $20.7 d$ & $15.2 \mathrm{c}$ & $74.0 \mathrm{~d}$ & $68.7 c$ & $50.2 c$ & $39.7 d$ & $29.5 d$ & 19.7d \\
\hline
\end{tabular}

*Values followed by the same letters within a column for each growth regulator are not significantly different $(\mathrm{P}=0.05)$.

Kinetin has been demonstrated to ameliorated the salinity-induced germination inhibition in Utah pickleweed, ${ }^{9}$ Brassica campestris L, ${ }^{41}$ Zygophyllum simplex L. ${ }^{29}$ Halopyrum mucronatum, ${ }^{14}$ Salicornia rubra, ${ }^{17}$ and Disticlis spicata Grene. ${ }^{19}$ It has also been shown to partially ameliospeed salinity inhibitory effects on seed germination of mesquite, ${ }^{13}$ seaside arrow grass, ${ }^{27}$ and Aeluropus lagopoides (L.) Trin. ex Thw. ${ }^{30}$ However, it had no effect on the salinity-induced dormancy in Sporobolus ioclados Nees ex Trin and Urochondra setulosa Trin, ${ }^{30}$ Salicornia pacifica Standl. ${ }^{42}$ Zygophyllum qatarense, ${ }^{15}$ Sporobolus arabicus Boiss, ${ }^{23}$ Cressa cretica L. and Suaeda fruticosa auct. non Forsk. Salsola imbricate Forssk. and Haloxylon stocksii Boiss. ${ }^{30,9}$ Khan and Ungar ${ }^{14}$ suggested that the addition of kinetin likely overcomes the deficiency in growth-promoting substances that are inhibited in salt-stressed seeds. The increase in seed germination under high salinity after exogenous application of kinetin was attributed to the ability to enhance water uptake during germination. ${ }^{43}$ 
Miller ${ }^{44}$ suggested that kinetin effect on the breaking of dormancy and promotion of seed germination may result from its combination of influences on cell division and enlargement. Also, kinetin enhances the biosynthesis of ethylene. As discussed previously, ethylene or ethylene-releasing compounds enhance germination when seeds are exposed to salt stress.

Table 3 Effect of different concentration of ethophon, fusicoccin, thiourea and kinetin on Glaucium spp seed germination speed under different salinity levels

\begin{tabular}{|c|c|c|c|c|c|c|c|c|c|c|c|c|c|}
\hline \multirow{3}{*}{$\begin{array}{l}\text { G. } \\
\text { Regulator }\end{array}$} & \multirow{3}{*}{ Level } & \multirow{2}{*}{\multicolumn{3}{|c|}{$\begin{array}{l}\text { G. acutidentatum } \\
\text { Salinity Level (dS/m) }\end{array}$}} & \multirow{2}{*}{\multicolumn{3}{|c|}{$\begin{array}{l}\text { G. corniculatum } \\
\text { Salinity Level (dS/m) }\end{array}$}} & \multirow{2}{*}{\multicolumn{3}{|c|}{$\begin{array}{l}\text { G. flavum } \\
\text { Salinity Level (dS/m) }\end{array}$}} & \multirow{2}{*}{\multicolumn{3}{|c|}{$\begin{array}{l}\text { G. grandiflorum } \\
\text { Salinity Level (dS/m) }\end{array}$}} \\
\hline & & & & & & & & & & & & & \\
\hline & & 0 & 15 & 30 & 0 & 15 & 30 & 0 & 15 & 30 & 0 & 15 & 30 \\
\hline \multirow[t]{4}{*}{ Thiourea } & $10 \mathrm{mM}$ & $* 13.2 \mathrm{c}$ & $\mathrm{IIb}$ & $7.4 c$ & $9.2 c$ & $6.5 c$ & $3.5 c$ & $22.8 c$ & $18 c$ & $14 c$ & $11.8 \mathrm{c}$ & $10.1 \mathrm{c}$ & $8.3 c$ \\
\hline & $20 \mathrm{mM}$ & $13 b$ & $\mathrm{IIb}$ & $7.4 b$ & $11.9 \mathrm{~b}$ & $7.2 \mathrm{~b}$ & $3.8 b$ & $26.2 b$ & $18.5 b$ & $14.6 \mathrm{~b}$ & $15.1 \mathrm{~b}$ & $\mathrm{II} .4 \mathrm{~b}$ & $8.8 b$ \\
\hline & $30 \mathrm{mM}$ & $19 a$ & $13 a$ & $8.5 a$ & $14.5 \mathrm{a}$ & $7.5 \mathrm{a}$ & $5 a$ & $29 a$ & $19.3 \mathrm{a}$ & $17.2 \mathrm{a}$ & $17.4 \mathrm{a}$ & $13.6 \mathrm{a}$ & $9.5 \mathrm{a}$ \\
\hline & Con. & $9.3 d$ & $7.8 \mathrm{c}$ & $5.5 d$ & $5.5 d$ & $3.3 \mathrm{~d}$ & $2.2 d$ & $20.8 d$ & $17.2 \mathrm{~d}$ & $13 d$ & $10.9 d$ & $8.5 d$ & $7 d$ \\
\hline \multirow[t]{4}{*}{ Fusicoccin } & $0.003 \mathrm{mM}$ & $10.4 \mathrm{c}$ & $5.5 d$ & $3.2 \mathrm{c}$ & $4.5 d$ & $3.8 \mathrm{~b}$ & $2.5 b$ & $21.5 c$ & $17.6 c$ & $14 c$ & $\mathrm{IIb}$ & 7.Id & $6.1 d$ \\
\hline & $0.005 \mathrm{mM}$ & $11.2 b$ & $6.4 b$ & $3 d$ & $5 c$ & $2.4 d$ & $2 d$ & $25.2 b$ & $18.5 b$ & $14.1 \mathrm{~b}$ & $\mathrm{IIb}$ & $9 b$ & $7.4 b$ \\
\hline & $0.01 \mathrm{mM}$ & $17.7 \mathrm{a}$ & $11.8 \mathrm{a}$ & $7.7 \mathrm{a}$ & $12.8 \mathrm{a}$ & $6.8 \mathrm{a}$ & $5 a$ & $27.7 \mathrm{a}$ & $19.1 \mathrm{a}$ & $14.5 \mathrm{a}$ & $17.4 \mathrm{a}$ & $13.1 \mathrm{a}$ & $9.2 \mathrm{a}$ \\
\hline & Con. & $9.3 d$ & $7.8 \mathrm{c}$ & $5.5 b$ & $5.5 b$ & $3.3 c$ & $2.2 \mathrm{c}$ & $20.8 d$ & $17.2 \mathrm{~d}$ & $13 d$ & $10.9 c$ & $8.5 c$ & $7 c$ \\
\hline \multirow{3}{*}{ Ethephon } & $5 \mathrm{mM}$ & $16.3 \mathrm{~b}$ & $8.8 b$ & $6.2 b$ & $9 b$ & $7.5 \mathrm{~b}$ & $2.7 \mathrm{~b}$ & $24 b$ & $19.4 \mathrm{~b}$ & $15.2 \mathrm{~b}$ & $15 b$ & $\mathrm{IIb}$ & $9 b$ \\
\hline & $10 \mathrm{mM}$ & $23 a$ & $14.6 \mathrm{a}$ & $12 \mathrm{a}$ & $18.2 \mathrm{a}$ & $8.8 a$ & $4.5 a$ & $31 \mathrm{a}$ & $20.3 a$ & $17.7 \mathrm{a}$ & $19.2 \mathrm{a}$ & $15.3 \mathrm{a}$ & $11.5 \mathrm{a}$ \\
\hline & Con. & $9.3 d$ & $7.8 \mathrm{~d}$ & $5.5 c$ & $5.5 d$ & $3.3 \mathrm{~d}$ & $2.2 c$ & $20.8 d$ & $17.2 \mathrm{~d}$ & $13 d$ & $10.9 d$ & $8.5 d$ & $7 d$ \\
\hline \multirow[t]{4}{*}{ Kinetin } & $0.5 \mathrm{mM}$ & $10.7 c$ & $6 d$ & $4.9 d$ & $7.8 c$ & $2.7 d$ & $1.6 \mathrm{c}$ & $20.8 c$ & $15 d$ & $11.8 \mathrm{~d}$ & $14.8 \mathrm{c}$ & $\mathrm{IIC}$ & $8.1 c$ \\
\hline & $1.0 \mathrm{mM}$ & $13.5 b$ & $8 b$ & $5.4 c$ & $8 b$ & $3.8 \mathrm{~b}$ & $2.2 b$ & $22 b$ & $17.7 \mathrm{~b}$ & $12.4 \mathrm{c}$ & $15.1 \mathrm{~b}$ & $11.9 \mathrm{~b}$ & $8.8 b$ \\
\hline & $1.5 \mathrm{mM}$ & $2 \mathrm{la}$ & $15.7 \mathrm{a}$ & $10 \mathrm{a}$ & $15.3 \mathrm{a}$ & $8.1 \mathrm{a}$ & $4 a$ & $29.3 a$ & $18.8 \mathrm{a}$ & $15.3 \mathrm{a}$ & $17.6 \mathrm{a}$ & $14.1 \mathrm{a}$ & $10 a$ \\
\hline & Con. & $9.3 d$ & $7.8 c$ & $5.5 b$ & $5.5 d$ & $3.3 c$ & $2.2 b$ & $20.8 c$ & $17.2 \mathrm{c}$ & $13 b$ & $10.9 d$ & $8.5 \mathrm{~d}$ & $7 d$ \\
\hline
\end{tabular}

*Values followed by the same letters within a column for each growth regulator are not significantly different $(\mathrm{P}=0.05)$.

Analysis of variance indicated a significant difference among tested chemicals at $\mathrm{EC}=0.0 \mathrm{dSm}-1, \mathrm{EC}=15 \mathrm{dSm}-1$ and at $\mathrm{EC}=30 \mathrm{dSm}-1$, (Table 1), in their effect on enhancing Glaucium spp seed germination percentage and germination speed. In conclusion, the tested species varied significantly in their variation in germination percentage and speed. Glaucium flavum achieved the greatest germination percentage and speed under all salinity levels followed by G. acutidentatum and G. grandiflorum while G. corniculatum had the lowest germination percentage and speed. The effect of growth regulators varied from species to species and from one salinity level to another. The current investigation showed that $30 \mathrm{mM}$ thiourea, $0.01 \mathrm{mM}$ fusicoccin, $10.0 \mathrm{mM}$ ethephon and $1.5 \mathrm{mM}$ kinetin increased seed germination percentage and speed of Glaucium spp under saline conditions. Ethephon was the most effective growth regulator in ameliorating salinity effect on Glaucium spp seed germination followed by kinetin, thiourea, and fusicoccin. All tested growth regulators had similar positive effects at the highest salinity level $(\mathrm{EC}=30 \mathrm{dSm}-1)$. More research is needed to develop appropriate protocols for practical and effective treatment procedures for landscape use restoration of saline areas. $^{45,46}$

\section{Acknowledgments}

None.

\section{Conflicts of interest}

Authors declare that there is no conflict of interest.

\section{References}

1. Grey Wilson C. Poppies: A guide to the poppy family in the wild and in cultivation. Timber Press, Portland; 2000.

2. Davis PH. Flora of turkey and the east aegean islands, Cruciferae. Edinburgh University Press, Edinburgh, 1965(1);248-495.

3. Scott GAM. Biological flora of the british isles: glauciumflavum crantz. Journal of Ecology. 1963;51:743-753.

4. Formanowiczowa H, Kozlowski J. Biology of germination of medicinal plant seeds. Part XIIIb. The seeds of glaucium flavum cr. - a medicinal plant from papaveraceae. Herba Polonica. 1976;22:284-290.

5. Mermerska E. Recherches sur le pouvoir germinatif des graines du glaucium flavum crantz. var. lejocarpum boiss. Acta Horticulturae. 1984;144:91-97.

6. Thanos CA, Georghiou K, Skarou F. Glaucium flavum seed germination an ecophysiological approach. Annals of Botany. 1989;63:121-130.

7. Walmsley CA, Davy AJ. The restoration of coastal shingle vegetation: effects of substrate on the establishment of container grown plants. Journal of applied ecology. 1997;154-165.

8. Elsner KC. Overcoming seed dormancy in glaucium spp. (Papaveraceae). Master thesis, Colorado State University.2007;88.

9. Gul B, MA Khan. Effect of growth regulators and osmotica in alleviating salinity effects on the germination of Salicornia utahensis. Pak J Bot. 2003;35:877-886. 
10. Whitehead CS, RM Nelson. Ethylene sensitivity in germinating peanut seeds: The effect of short-chain saturated fatty acids. J Plant Physiol. 1992; 138:479-483.

11. Sutcliff MA, CS Whitehead. Role of ethylene and short chain saturated fatty acids in the smoke-stimulated germination of Cyclopea seeds. $J$ Plant Physiol. 1995;145:33-36.

12. Khan AA, C Andreoli. Role of ethylene biosynthesis in seed germination and stand establishment under stress. In: CG Kuo, editor. Adaptation of food crops to temperature and water stress. Proc of an In Symp. Asian vegetable research and development center (AVRDC), Taiwan;1993;81-90.

13. El-KeblawyA, F Al-Ansari, AAl-Rawai. Effects of dormancy regulating chemicals on innate and salinity induced dormancy in the invasive Prosopis julifl ora (Sw.) DC shrub. Plant Growth Reg. 2005;46(2):161168.

14. Khan MA, IA Ungar. Alleviation of salinity stress and the response to temperature in two seed morphs of Halopyrum mucronatum (Poaceae) Aust J Bot. 2001;49(6):777-783.

15. Ismail AMA. Germination ecophysiology in populations of Zygophyllum qatarense Hadidi from contrasting habitats: Effect of temperature, salinity and growth regulators with special reference to fusicoccin. J Arid Environ. 1990;18:185-194.

16. Gul B, MA Khan, DJ Weber. Alleviation salinity and dark-enforced dormancy in Allenrolfea occidentalis seeds under various thermoperiods Aust J Bot. 2000;48:745-752.

17. Khan MA, B Gul, DJ Weber. Improving seed germination of Salicornia rubra (Chenopodiaceae) under saline mconditions using germinationregulating chemicals. West Nor Amer Nat. 2002;62:101-105.

18. Gulzar S, MA Khan. Comparative growth, water and ion relations of perennial halophytic grasses. In 8th National Meeting of Plant Scientists, Karachi, Pakistan; 2003;24-28.

19. Shahba MA, YL Qian, KD Lair. Improving seed germination of saltgrass under saline conditions. Crop science. 2008;48:756-762.

20. Shahba MA, QianY, S Wallner. Influence of proxy on saltgrass seed germination in saline soil. International Turfgrass Society. 2009;11:849858

21. SAS Institute. SAS/STAT user's guide. SAS Institute, Cary, NC. 2006.

22. Khan MA, IA Ungar. Germination of salt tolerant shrub suaeda fruticosa from Pakistan: Salinity and temperature responses. Seed Sci Technol. 1998;26:657-667.

23. Khan MA, IA Ungar. Effect of germination promotin compounds on the release of primary and salt-enforced seed dormancy in the halophyte sporobolus arabicus Boiss. See Sci Technol. 2001:29;299-306.

24. Ungar IA. Ecophysiology of vascular halophytes. CRC Press, Boca Raton, FL. 1991

25. Khan MA, B Gul. Ecophysiology of high salinity tolerant plant. Tasks for vegetation science. 2006;34(40):11-30.

26. Ungar IA.. Seed germination and seed-bank ecology of halophytes. In: Kigel, G Galili, editors. Seed development and germination. New York Marcel and Dekker Inc. 1995.

27. Khan MA, IA Ungar. Seed germination of Triglochin maritima as influenced by salinity and dormancy relieving compounds. Biol Plant. 2001;44(2):301-303.
28. Khan MA, IA Ungar, B Gul. Alleviation of salinity enforced seed dormancy in Action Atriplex prostrata. PakJ Bot. 2003;36:907-912.

29. Khan MA, IA Ungar. Alleviation of seed dormancy in the desert forb Zygophyllum simplex L. from Pakistan. Ann. Bot. (Lond.). 1997;80(4):395-400.

30. Gulzar S, MA Khan. Alleviation of salinity-induced dormancy in perennial grasses. Biol Plant. 2002;45:617-619.

31. Siddiqui ZS, SH Shaukat, AU Zaman. Alleviation of salinity-induced dormancy by growth regulators in wheat seeds. Turk J Bot. 2006;30:321330 .

32. Eashi Y, Y Ohara, M Okazaki, et al. Control of cocklebur seed germination by nitrogenous compounds: Nitrite, nitrate, hydroxylamine, thiourea, azide, and cyanide. Plant Cell Physiol. 1979;20:349-361.

33. Kabar K, S Baltepe. Eff ects of kinetin and gibberellic acid in overcoming high temperature and salinity $(\mathrm{NaCl})$ stresses on the germination of barley and lettuce seeds. Phyton (Buenos Aires). 1990;30:65-74

34. Marre, E. Fusicoccin: A tool in plant physiology. Annu Rev Plant Physiol. 1979;30:273-288

35. Cocucci SM, S Morgutti, A Abruzzese, et al. Response to osmotic medium and fusicoccin by seeds of radish (Raphanus sativus) in the early phase of germination. Physiol Plant. 1990;80:294-300.

36. Lutsenko EK, EA Marushko, NV Kononenko, et al. Effects of fusicoccin on the early stages of Sorghum growth at high $\mathrm{NaCl}$ concentrations. Russ J Plant Physiol. 2005;52:332-337.

37. Lado P, F Rasi-Caldogno, R Colombo. Promoting effect of fusicoccin on seed germination. Physiol Plant. 1975;34:359-364.

38. Schonbeck MW, GH Egley. Phase-sequence of redroot pigweed seed germination responses to ethylene and other stimuli. Plant Physiol. $1981 ; 68: 175-179$

39. Khan MA, IA Ungar, B Gul. Action of compatible osmotica and growth regulators in alleviating the eff ect of salinity on the germination of dimorphic seeds of Arthrocnemum indicum L. Int J Plant Sci. 1998; 159:313-317.

40. Khan MA, IA Ungar. Seed germination and of Polygonum aviculare L. as infl- uenced by salinity, temperature and gibberellic acid. Seed Sci Technol. 1998;26:107-117.

41. Ozturk M, M Gemici, C Yilmazer, et al. Alleviation of salinity stress by GA, KIN, and IAA on seed germination of Brassica campestris L. Doga Tu Bot Dergisi. 1993;17:47-52.

42. Khan MA, DJ Weber. Factors influencing seed germination in Salicornia pacifi ca var. Utahensis. Am J Bot. 1986;73:1163-1167.

43. Sastry EVD, KS Shekhawat. Alleviatory effect on GA3 on the effects of salinity at seedling stage in wheat (Triticum aestivum). Indian J Agric Res. 2001;35:226-231.

44. Miller CO. Kinetin and related compounds in plant growth. Annu Rev Plant Physiol. 1961;12:395-408.

45. Kopec DM, K Marcum. Desert saltgrass: A potential new turfgrass species. USGA Green Section Rec. 2001;39:6-8.

46. Seneca ED. Germination and seedling response of atlantic and gulf coasts populations of uniola paniculata. American Journal of Botany. 1972;59:290-296. 